\title{
Do agir contra a exclusão à competência comum: um retrospecto histórico e sociológico da gramática da economia solidária
}

Jéssica Maria Rosa Lucion'

FRÈRE, B. Le nouvel esprit solidaire. Paris: Desclée de brouwer, 2009. 432 p.

Le nouvel esprit solidaire é dedicado à reconstrução das regras morais que regem a economia solidária, para tal, o autor se apoia no discurso de instituiçôes francesas que coordenam projetos e empreendimentos solidários.

A primeira parte do livro é dedicada à exposição do ethos solidário, fazendo-se menção aos dois principais regimes morais que compóem a gramática da economia solidária ${ }^{2}$, cujas raízes estariam no pensamento dos autores revolucionários franceses do século XIX, dando-se especial atenção à influência exercida pela obra de Proudhon.

Para Proudhon, tanto a estrutura social calcada na propriedade privada, como a orientada pelo princípio comunitário não seriam sistemas sociais ideais; nesse sentido, ele propóe uma síntese denominada sistema mutualista. A nova ordem imaginada por Proudhon prescinde de associaçôes econômicas livres, por meio das quais a produção e a comercialização seja feita de forma igualitária e justa. $\mathrm{O}$ mutualismo caracteriza-se pelo

[...] homem livre, realmente soberano, agindo sob sua própria iniciativa e sua responsabilidade pessoal; certo de obter por seus produtos e serviços um preço justo, suficientemente

1 Graduada em Ciências Sociais. Mestranda em Ciências Sociais na Universidade Federal de Santa Maria (UFSM).E-mail: jessicalucion@hotmail.com

2 É a partir do registro teórico da sociologia pragmática de Luc Boltanski que o conceito de gramática é mobilizado por Frère (2009) para compreender os limites da economia solidária. Nesse sentido, uma gramática "[...] é constituida de um conjunto de regras que permitem aos atores convergir seus julgamentos e ações a partir de suas experiências e do produto que as sustenta" (NACHI, 2006, p. 46). 
remunerador, e de reencontrar entre seus concidadãos, através de todos os objetos de seu consumo, a lealdade e as garantias mais perfeitas. (apud RESENDE; PASSETTI, 1986, p. 122).

Proudhon compreende que a revoluçáo social se expressa nessas novas formas de organização econômica eminentes do mutualismo. A experiência das oficinas de tecelagem no século XIX teria dado à Proudhon base empírica para a construção do sistema mutualista. Essas oficinas seriam, simultaneamente, locais de trabalho para os tecelóes e de formação para os desempregados que seriam seus aprendizes.

A práxis revolucionária pensada por Proudhon estaria sendo praticada por esses tecelóes na medida em que essas iniciativas seriam uma forma de agir contra a exclusáo social, bem como colocar em contato os membros das classes médias e os desempregados. Esses profissionais estariam motivados a capacitar os indivíduos excluídos para agirem autonomamente, tornando comum, entre os dois, a competência para agir. Para Proudhon, entre eles, predominaria um espírito de igualdade e solidariedade. Imaginar essa simetria envolve o entendimento de que ambos têm competência idêntica de ação e que isso poderia levar à formação de redes solidárias de produção, consumo e serviços.

Ao se apresentarem um ao outro, envolvidos por um espírito de equidade e simpatia, classes médias e excluídos reconheceriam a sua capacidade comum para a açáo e o seu agir contra a exclusão social, os quais são, para Frère (2009), os dois principais regimes morais da economia solidária, e que têm, portanto, raízes nos princípios mutualistas idealizados por Proudhon. É por isso que o discurso das instituiçôes analisado na obra em tela está relacionado ao imaginário solidário presente em Proudhon de modo que existiria uma convergência entre as associaçóes idealizadas por ele e a economia solidária no século XX.

Segundo Frère (2009), até o século XX, as cooperativas de produção, que constituíam o corpo principal da economia social na Europa, sustentaram essa gramática própria do mutualismo. Para o autor, isso aponta para a primeira crise da modernidade ${ }^{3}$, caracterizada pelo surgimento de novas formas de

3 Partindo das definições de Wagner (1996 apud FRÈRE, 2009), Frère menciona as duas crises enfrentadas pela modernidade que teriam desconstruido suas formulações genuinas: autonomia individual e racionalidade instrumental. 
Do agir contra a exclusão à competência comum: um retrospecto histórico e sociológico da gramática da economia solidária| Jéssica Maria Rosa Lucion

organização econômica e política, e marcada pelo protagonismo do movimento operário, visto que buscava atacar as restriçóes impostas a estes pelo advento da modernidade. No entanto, após a Segunda Guerra Mundial, as cooperativas foram incorporadas pelas classes médias, havendo o desencantamento da representação do mundo proudhoniano. As cooperativas já não eram mais vistas como uma ação revolucionária, mas como um setor da economia capitalista, a voz operária foi reprimida e o estado reforçou a economia de mercado.

Uma das reaçôes à economia de mercado e à despreocupação com as questôes sociais, que se inflamou a partir de então, é a possibilidade de democratização social via reapropriação econômica, uma vez que uma concepção de sociedade centrada em direitos individuais e na redistribuiçáo de renda não é suficiente. É necessário ampliar as relaçôes sociais baseadas na igualdade; desta forma, estado e sociedade civil deveriam se unir para promover açóes de emancipação.

$\mathrm{O}$ autor de Le nouvel esprit solidaire enfatiza que a emergência da economia solidária francesa está associada à problemática da crise do estado-providência. Ela emerge da falência dos mecanismos de regulaçáo da sociedade (mercado e estado), da economia social que diminui suas açóes de combate à pobreza e da benevolência cristã que cresce nos extratos médios. As classes médias, incentivadas por entes religiosos, decidem apoiar e promover iniciativas de emancipação, desenvolvimento de capacidades e autonomia dos indivíduos excluídos. Essa práxis é similar àquela visualizada anteriormente, quando membros das classes médias, no século XIX, contribuíram para as primeiras formas de ajuda mútua por meio das oficinas de tecelagem. Quando o estado se retira de cena como investidor social, há, em curso, o engajamento cívico das classes médias e dos excluídos na luta contra a pobreza. Este ressurgimento da economia social em meados do século XX é que irá estabelecer o caminho para as experiências posteriores de economia solidária.

A segunda parte do livro dedica-se ao surgimento de experiências "alternativas". É com o nascimento delas que surge o novo espírito solidário, investigado na obra, materializado em açóes de inclusão socioeconômica que têm por compromisso político a construção de um mundo mais justo, destinando-se, principalmente, aos desempregados e trabalhadores precários.

$\mathrm{Na}$ década de 1960, a instabilidade social, principalmente em torno do trabalho, começou a assumir novos contornos, como a desestabilização, 
a precariedade e o déficit de postos de trabalho. Assim, surgiu a erosão da identidade operária, a qual deu lugar à sociedade salarial. Há, portanto, um desenraizamento social que, segundo Frère (2009), aponta para a segunda crise da modernidade. Na década de 1970, o surgimento da economia solidária procurou responder a essa crise e propor um novo compromisso filiado à noção de humanidade, simbolizando o ponto inicial para o desenvolvimento de uma economia alternativa.

A economia solidária tenderia a quatro desdobramentos principais. As micro finanças ou poupanças solidárias visavam a democratizar os recursos econômicos para que as finanças estejam a serviço de todos e uma das suas mais conhecidas expressóes sáo os Bancos Populares ou Comunitários.

Para o autor da obra em tela, o crédito mútuo encontra-se no cerne da justificação solidária dos atores que ele investigou como os Cigales4. Nas chamadas trocas solidárias, pratica-se o intercâmbio multilateral de bens e serviços, utilizando-se principalmente um sistema de troca não monetário via trocas diretas ou pelo uso de moedas sociais com o objetivo de superar a escassez de papel-moeda. Já o comércio justo é definido como um sistema de solidariedade concreta entre os consumidores dos países do Norte e os pequenos produtores dos países do Sul. Nesse comércio, os primeiros se comprometem a comprar dos últimos a um preço justo, considerando os custos reais de produçáo. E os produtores do Sul comprometem-se em organizar a produçáo de forma democrática, respeitando o meio ambiente e a sociedade. Por fim, há os serviços de proximidade, que são um vasto conjunto de atividades de apoio à vida cotidiana, como serviços domésticos, culturais e de lazer. Conforme aponta Frère (2009), a história dos serviços de proximidade é, em grande parte, a história da centralização da atenção em torno dos excluídos: desde o final da década de 1980, as agências destes serviços trabalharam pela integração dos excluídos por meio da atividade econômica. $\mathrm{O}$ público assistido não é considerado beneficiário, mas ator do seu próprio desenvolvimento.

4 Conforme definição própria, as Cigales são agências de crédito solidário, ou seja, configuram um capital de risco solidário constituído a partir da poupança de seus membros (5 a 20 pessoas é o número de membros necessário para compor um Clube Cigale), para fomentar o desenvolvimento de pequenas empresas no âmbito da economia solidária. A primeira Cigale, denominada ALDEA (Agence de Liaison pour le Développement de l'Economie Alternative), foi criada no início da década de 1980 do século XX. mais especificamente em 1983. Para maiores detalhes, consultar Cigales, 2015. 
Cabe, ainda, ressaltar o potencial crítico da economia solidária entendida como uma renovação da crítica social ao sistema capitalista. Para Boltanski e Chiapello (2009), de um modo geral, a crítica ao capitalismo vem se orientando contra as mesmas provas: do sistema como fonte de desencanto e de inautenticidade, de opressão, como fonte, cada vez mais ampla, de miséria e de desigualdades e de oportunismo e egoísmo. Frère (2009) identifica que os atores da economia solidária, gradualmente, transitam da crítica estética do capitalismo a uma crítica social ${ }^{5}$. Para o autor, essas críticas têm, no entanto, origens diferentes: a estética nasce com as elites socioculturais; a social com as vítimas do advento da economia de mercado e baseia-se no questionamento econômico e político do modelo de desenvolvimento adotado.

Seguindo o argumento de Boltanski e Chiapello (2009), Frère (2009) indica que sem a manutenção de uma forte crítica social, os empreendimentos de economia solidária, provavelmente náo seriam capazes de se distinguir de micro empresas capitalistas. Entáo, para que se analise o potencial crítico da economia solidária, o autor utiliza como exemplo a experiência da Rede de Economia Alternativa e Solidária (REAS) - a tentativa mais bem-sucedida de federação das iniciativas de economia alternativa; afinal, depois da sua criação, o termo "alternativo" entrou em desuso, de maneira a enfatizar a transição efetuada pela economia solidária de uma crítica radical para uma crítica corretiva em relaçáo ao sistema capitalista. Compreender esse processo torna-se importante para entender algumas críticas que lhe sáo direcionadas e que evidenciam seus limites em constituir-se enquanto "outra economia", com "outro espírito", divergente do ideário liberal.

Nas conclusóes do trabalho, questiona-se a possibilidade de a economia solidária ter força para resolver a crise salarial da sociedade moderna. Para o autor, a resposta mais segura seria que a economia solidária é "uma das possíveis soluçôes” em uma gama de diferentes possibilidades (FRÈRE, 2009).

5 Segundo Boltanski e Chiapello (2009), as duas formas de críticas foram, historicamente, mobilizadas por diferentes atores; no entanto, em diversas ocasiões, é possivel encontrá-las unidas em um mesmo discurso crítico, como é o caso dos movimentos revolucionários franceses do século XIX e XX. A crítica estética invoca a perda de sentido provocada pelo processo de tecnificação, padronização e mercantilização decorrente do modo de agir capitalista que atinge não apenas os seres humanos, mas também a esfera artística. Ela pode ser entendida como uma recusa ao processo de desencantamento do mundo. A crítica social inspira-se nos ideais socialistas e marxistas e indigna-se com relação ao egoísmo, à exploração capitalista e à miséria das classes mais pobres. 
Além disso, Frère aponta que a economia solidária não tem a ambição de substituir a economia de mercado, mas de resolver os problemas dos excluídos e as necessidades negligenciadas pelo mercado e pelo Estado. Assim, é provável que economia solidária evolua para iniciativas de inserção ou de proteção do trabalho dos "marginalizados", independentemente da sua capacidade de dar base a uma prática econômica diferenciada.

As iniciativas das instituiçóes analisadas por Frère (2009) seriam exemplos de "pequenas revoluçóes", menos ambiciosas que a práxis proposta por Proudhon; porém, consideradas mais realistas, conforme relata um dos representantes da REAS, “[...] positions moins ambitieuses em apparence que celle des révolutionnaires, mais tellement plus radicales que les impasses gestionnaires ou technocratiques, c'est ici et maintenant que prennent racines nos utopies" (FRÈRE, 2009, p. 56).

Le nouvel esprit solidaire se debruça sobre os aspectos micro sociais, relacionados à dinâmica interna dos atores envolvidos com a economia solidária, dando menor atenção à discussão macro social, mais comum nos estudos sobre o tema, o qual questiona a possibilidade de a economia solidária ser uma alternativa ao sistema capitalista ou uma extensão deste. Além disso, pode-se afirmar que a obra tem considerável importância para os pesquisadores do campo da economia solidária, náo por apenas descrever a gramática que permeia o agir dos indivíduos excluídos, mas por reconstruí-la histórica e sociologicamente, tornando possível pensar, a partir disso, não apenas a economia solidária francesa mas também a brasileira, visto que ambas possuem diversas semelhanças.

\section{Referências}

BOLTANSKI, L.; CHIAPELLO, É. O novo espírito do capitalismo. Rio de Janeiro: Martins Fontes, 2009.

CIGALES. Qu'est-ce qu'une Cigales ?. 2015. d.]. <http://cigales.asso.fr>

NACHI, M. Introduction à la sociologie pragmatique. Paris: Armand Colin, 2006.

ReSENDE, P.; PASSETTI, E. (Org.). Pierre - Joseph Proudhon: Política. São Paulo: Ática, 1986.

Recebido: 23.10 .2014

Aceito: 16.03 .15

$177-181$ 